\title{
The Prevalence of the Citrus tristeza virus Trifoliate Resistance Breaking Genotype Among Puerto Rican Isolates
}

Avijit Roy and Nandlal Choudhary, University of Florida, Plant Pathology Department, Citrus Research and Education Center, Lake Alfred 33850; John S. Hartung, USDA-ARS, MPPL, Beltsville Agricultural Research Center, Beltsville, MD 20705; and R. H. Brlansky, University of Florida, Plant Pathology Department, Citrus Research and Education Center, Lake Alfred 33850

\begin{abstract}
Roy, A., Choudhary, N., Hartung, J. S., and Brlansky, R. H. 2013. The prevalence of the Citrus tristeza virus trifoliate resistance breaking genotype among Puerto Rican isolates. Plant Dis. 97:1227-1234.

Citrus tristeza virus (CTV) isolates have been grouped into six genotypes: T3, T30, T36, VT, B165, and resistance breaking (RB) based on symptoms, host range, and genomic sequence data. The RB genotype has recently been identified with the novel property of replicating in trifoliate orange trees, a resistant host for the other five genotypes. Puerto Rican CTV isolate B301 caused mild vein clearing symptoms in Mexican lime but did not induce seedling yellows or stem pitting reactions in appropriate indicator Citrus spp., which are typical host reactions of the isolate $\mathrm{T} 30$. The isolate $\mathrm{B} 301$ was not detected by the genotype specific primer (GSP), which identifies the CTV-T3, -T30, -T36, -VT, and B165 genotypes. A primer pair for reverse transcription polymerase chain reaction (RT-PCR) amplification of the CTV-RB genotype was designed from the heat shock protein (p65) region based

on the complete genomic sequences of trifoliate RB isolates from New Zealand available in the GenBank databases. The amplicon sequence from isolate B301 was $98 \%$ identical to that of the other trifoliate RB isolates. In addition, B301 was successfully inoculated into 'Carrizo citrange' (a trifoliate hybrid) but did not induce any symptoms. Furthermore, the complete genome sequence of B301 followed by the phylogenetic analysis revealed that the isolate is part of the RB clade with other CTV-RB isolates from New Zealand and Hawaii. Additional CTV isolates obtained from Puerto Rico were tested with the RB-GSP and confirmed the presence of trifoliate RB isolates in mixed infection with known CTV genotypes. Although this is the first report of a CTV trifoliate RB genotype from Puerto Rico, this genotype was present there prior to 1992 .
\end{abstract}

Citrus tristeza virus (CTV) is a phloem-limited Closterovirus generally restricted to two plant genera (Citrus and Fortunella) within the family Rutaceae $(23,29)$. In the last 80 years, CTV has been considered the most important viral pathogen of Citrus spp. $(4,23)$. Isolates of CTV differ in their pathogenicity on various host species and cultivars and usually fall into one or more symptom categories $(11,24)$. CTV may be present as a single or a mixture of multiple genotypes, and one of the genotypes often predominates in a mixed infection $(2,3,6,32,34)$. Plants infected with CTV often have defective CTV-related RNAs (dRNAs) $(20,48)$ and subgenomic RNAs (sgRNAs) $(15,18)$. Recombinant CTV genotypes may emerge from trees with mixed CTV infections over a long period, and these novel isolates may be spread by aphid vectors to other trees (47). The continued exploration of CTV isolates has increased the number of reference genotypes from four to six in recent years (T3, T30, T36, VT, B165, and trifoliate resistance breaking $[\mathrm{RB}])(13,33)$.

CTV has long filamentous virions $(2,000 \times 10-12 \mathrm{~nm})$ and is transmitted by several aphid species in a semi-persistent manner as well as by graft inoculation $(4,8)$. CTV has a single stranded positive sense RNA of $\sim 19.3 \mathrm{~kb}$, the largest genome of any plant virus. The CTV genome is encapsidated by two coat proteins (CP), a major $\mathrm{CP}$ covering $97 \%$ of the virion (body) and a minor $\mathrm{CP}$ $(\mathrm{CPm})$ on the $5^{\prime}$ end (tail) $(9,37)$. It encodes 12 open reading frames (ORFs) with two untranslated regions (UTRs) of about 107 and $273 \mathrm{nt}$ at the $5^{\prime}$ and $3^{\prime}$ termini, respectively $(17,27)$. The $5^{\prime}$

Corresponding author: R. H. Brlansky, E-mail: rhby@ufl.edu

* The $\boldsymbol{e}$-Xtra logo stands for "electronic extra" and indicates that two supplementary tables are available in the online edition.

Accepted for publication 29 March 2013.

http://dx.doi.org/10.1094/PDIS-01-12-0012-RE

(C) 2013 The American Phytopathological Society terminal half-region (ORFs 1a and 1b) proteins are expressed from the genomic RNA and encode the replicase domains for virus replication. The product of ORF1b is thought to continue through the RNA-dependent RNA polymerase (RdRp)-like domain by a +1 frame shift. The $3^{\prime}$ terminal half-region (ORF2-11) proteins are expressed by $3^{\prime}$-coterminal subgenomic RNAs (sgRNAs) $(15,18)$. The internally positioned genes translated by ORF4-7 are involved in assembly of virions (38). A hydrophobic protein (p6) translated through ORF3 may have a role in virus movement (43), whereas proteins p20 (ORF10) and p23 (ORF11) play a role in the suppression of RNA silencing along with the CP gene (19). Citrus trees can be infected with genotype CTV-T36 carrying deletions of $\mathrm{p} 33$ (ORF2), p18 (ORF8), and p13 (ORF9), suggesting that these genes are not essential for the viral infection in citrus plants (43). However, further study of these three nonconserved genes revealed that these genes are not essential for infection of some citrus species, but are essential for infecting others (40).

Genotype specific primers (GSPs) reverse transcription polymerase chain reaction (RT-PCR) for the five CTV genotypes were developed and used to categorize collections of CTV from Florida and global sources (30). Isolates B159 from Spain and B301 from Puerto Rico were positive for CTV by both enzyme-linked immunosorbent assay (ELISA) and RT-PCR for the CP gene. However, they could not be assigned to a genotype with the existing GSPs (30). Analysis of the complete genomic sequences of five New Zealand (NZ) trifoliate RB CTV isolates showed that all of the isolates clustered together to create a new recombinant CTV genotypic group, CTV-RB (13). The sequence of CTV-RB isolates was used to develop a pair of CTV-RB GSP which successfully amplified the target from isolate B301, indicating that CTV-B301 is likely to be a RB genotype. In this study, we successfully determined the full genome sequence of B301 isolate. Phylogenetic relationships were inferred between CTV-B301 and 21 other completely sequenced CTV isolates from different geographical regions $(1,12,13,17,21,22,27,33,35,41,46,49)$. This trifoliate RB genotype was present in Puerto Rico prior to 1992. Other Puerto Rican CTV isolates available at Exotic Pathogens of Citrus Collec- 
tion (EPCC) also were tested by RT-PCR utilizing the RB and other GSPs to determine if the RB genotype also was present in mixed infections.

\section{Materials and Methods}

Virus isolates. CTV isolate B301 budwood was originally collected from Aguas Buenas, Puerto Rico in 1992, and budwood was sent to the EPCC for biological evaluation in May 1993. The infected budwood was grafted and maintained in 'Madame Vinous' and 'Ridge Pineapple' sweet orange. B301 was inoculated by grafting to 'Mexican' lime (Citrus aurantifolia (Christm.) Swing.), sour orange $(C$. aurantium L.), 'Madame Vinous' sweet orange $(C$. sinensis (L.) Osb.), 'Duncan' grapefruit (C. paradisi Macf.), and sweet orange on sour orange root stock to evaluate the biological symptoms caused by CTV in these hosts: leaf reaction (LR), seedling yellows (SY), orange stem pitting (OSP), grapefruit stem pitting (GFSP), and decline (DL), respectively (11). In a previous study, 11 CTV symptom patterns were observed based on a symptoms rating scale of 0 (no symptoms) to 3 (severe symptoms) on the above-mentioned indicator hosts (11). CTV isolates B298, B300, B385, B386, B391, B392, B393, and B394 from Puerto Rico available at EPCC also were biologically evaluated and compared with the isolate B301 using the symptoms rating scale described by Garnsey et al. (11). Furthermore, B301 was also inoculated to 'Carrizo citrange' (a hybrid of Poncirus trifoliata and Washington navel sweet orange) to determine if it could replicate in this host. In addition, these CTV isolates were also tested for reaction with monoclonal antibody MCA13 by ELISA (28).

dsRNAs and total RNA extractions and identification of CTV genotype using RT-PCR amplification. Double stranded (ds) RNAs and total RNA from citrus seedlings infected with CTVB301 and other tested isolates as well as from healthy citrus seedlings were extracted using the CF-11 column method (45) and the RNeasy Plant Mini Kit (Qiagen, Valencia, CA) following the manufacturer's protocol. Isolated dsRNA was digested with RNaseA (Ribonuclease A, Bovine Pancreas; Calbiochem) to eliminate the single stranded (ss) RNA and confirmed the presence replicative form of specific CTV genotype. Furthermore, to improve the purity

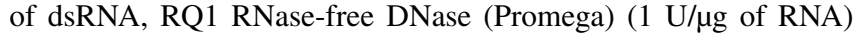
was added to remove ssDNA and dsDNA. Each digestion was performed at $37^{\circ} \mathrm{C}$ for 15 to 30 min following the manufacturer's instructions. The same dsRNA was used as template to produce CTV genotype specific and generic coat protein amplicons. Trifoli-

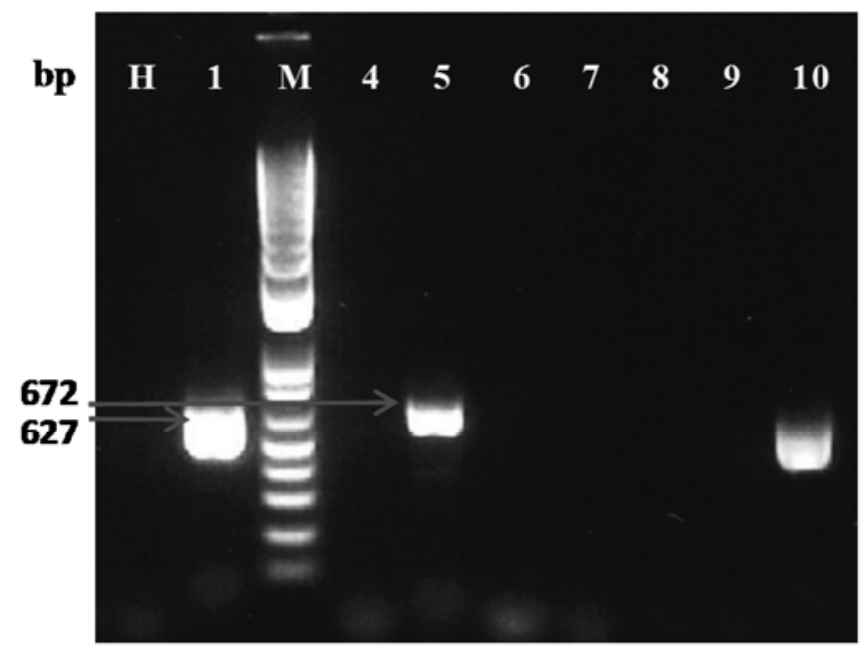

Fig. 1. Detection of Citrus tristeza virus isolate B301 using dsRNA as template and resistance breaking $(R B)$ genotype specific primers by reverse transcription polymerase chain reaction. Lanes: $H=$ healthy sweet orange plant, $M=1 \mathrm{~kb}$ plus DNA ladder from Invitrogen, 1 = CTV-B301, $4=-$ T36, 5 = -Coat protein gene amplicon (positive control), $6=-\mathrm{B} 165,7=-\mathrm{T} 3,8=-\mathrm{VT}, 9=-\mathrm{T} 30$, and $10=-\mathrm{NZ}-\mathrm{RB}$. The long arrow indicates the generic CTV coat protein gene amplicon, and the small arrow indicates the RB genotype specific amplicon. ate RB New Zealand CTV isolates CQ291 and NZ-KD8 obtained from the EPCC were used as positive controls in all RT-PCR tests, in order to standardize the detection method for the CTV-trifoliate RB genotype. RNA extracts obtained from CTV isolates T3, T30, T36, VT, and B165 were used as reference CTV genotypes, and extracts of healthy citrus seedling tissues were used as negative controls.

CTV-B301 genome amplification utilizing overlapping RTPCR. Several sets of degenerate and overlapping primers were designed for RT-PCR amplification based on the conserved regions of five CTV-RB isolate sequences from New Zealand and the other complete CTV genome sequences available in the GenBank. Twenty-three pairs of RT-PCR primers, which produced overlapping PCR products, were also designed based on the conserved regions of ORF1a through ORF11 to complete the genome sequence of isolate B301 (Supplementary Table 1). Synthesis of the first strand of cDNA followed by PCR was accomplished following previously described protocols $(30,33)$. Each amplicon contained a minimum of 150 to 250 shared nucleotides to maximize coverage for sequencing. The Poly (A) Polymerase (PAP) enzyme (Ambion, Foster City, CA) was utilized to add adenosine to the $3^{\prime}$ end of RNA in a sequence-independent fashion following the manufacturer's instruction. Then RNA Ligase Mediated Rapid Amplification of cDNA Ends (RLM-RACE) was used to allow the amplification of terminal sequences at the $5^{\prime}$ and $3^{\prime}$ ends of the mRNA (Ambion).

A region of ORF4 (p65) was selected as a target for detection of the CTV-RB genotype. The trifoliate RB genotype-specific forward (RB-p65F: ${ }^{12248}$ AAG YTA CTT GCA CAA GTT GTC ACC ATC TTA $^{12277}$ ) and reverse primers (RB-p65R3: ${ }^{12874}$ TGG TCG ATT GAT ACT GTT TCA CTA ATC CCA $\mathrm{T}^{12844}$ ) were designed, standardized, and used for detection of the CTV-RB genotype in single or mixed infections with T3, T30, T36, VT, and B165 genotypes following the simplex RT-PCR protocol described earlier (30). The nucleotide positions of the above-mentioned RB-GSP sequences are based on the trifoliate RB CTV isolate NZRB-G90 sequence (Accession number FJ525432). The species-specific CP gene (p25) primer pair was used as a universal positive control for all CTV isolates (30).

Cloning, sequencing, and sequence analysis. RT-PCR products were electrophoresed on $1.0 \%$ agarose gels. cDNA bands were excised, purified using a QIAGEN gel purification kit (Qiagen), and then directly ligated into a pGEM-T Easy Vector (Promega, Madison, WI) following the manufacturer's protocol. In all cases, at least three to five clones of each amplicon were bi-directionally sequenced utilizing ABI Prism 3100 automatic DNA Sequencer at the University of Florida (DNA Sequencing Core Laboratory, Gainesville, FL). All sequences were compared with other complete CTV genomes, then aligned and analyzed using the computer programs Clustal X (44) and GeneDoc version 2.6.002 (26). The complete nucleotide sequence of CTV isolate B301 was deposited in GenBank under the accession number JF957196.

Phylogenetic analysis of the complete genome. Phylogenetic analyses were performed on 21 full genome CTV sequences without fragmentation. As described previously (33), the $5^{\prime}$ and $3^{\prime}$ UTR were excluded from the complete CTV-B301 genome sequence prior to phylogenetic analysis of the individual ORFs. The intergenic regions between ORFs also were excluded to increase the degree of phylogenetic relationship of those regions. Individual ORFs were evaluated to determine if isolate B301 clustered with the other trifoliate RB isolates. Phylogenetic relationships were inferred using the MEGA5 software package (42). Reconstructions of phylogeny were created with 1,000 bootstrap replicates of the alignments by the Maximum Parsimony (MP) method using the Close Neighbor Interchange tree inference options (25). NeighborJoining (NJ) analysis method was selected to infer the evolutionary history of CTV-B301 with other CTV isolates $(10,36,50)$. The Maximum Likelihood (ML) and the Minimum Evolution (ME) methods in the MEGA5 package also were applied in parallel for comparison. The evolutionary divergence between CTV-B301 and the 21 previously sequenced CTV isolates were estimated using the p-distance method (42). 


\section{Results}

Trifoliate CTV-RB genotype specific primers for RT-PCR. The discovery of the RB genotype and the availability of complete sequences of other CTV-RB isolates in the GenBank expedited identification of nucleotide sequences conserved among RB isolates. This was achieved when the genomic sequences representing the five previously established CTV genotypes were aligned and compared with RB isolate sequences. In previous studies, the highly variable region of ORF1a and the overlapping regions of ORF1b and ORF2 were used to group CTV genotypes $(14,16,30,31)$. Since the CTV-RB genome is a recombinant of T36, T30, and VT genotypes in the variable region (13), the $5^{\prime}$ terminal half-regions were inappropriate for identification of the CTV-RB genotypes. Thus, we investigated the $3^{\prime}$ terminal half-regions of the CTV genome to define ORFs that could be used to differentiate between the CTV-RB and the previously defined CTV genotypes (T3, T30, T36, VT, and B165). Nucleotide sequence identity and phylogenetic analysis identified ORF4 as a region to design the RB GSPs. The RB-GSPs successfully amplified a 627-bp amplicon from this region of the Puerto Rican isolates B300, B301, B386, B391, and two NZ-RB isolates (NZ-KD8 and CQ291), but not from the CTV reference genotypes T3, T30, T36, VT, and B165, as shown for B301 (Fig. 1). The four Puerto Rican isolates showed 96 to $98 \%$ nucleotide sequence identities with the NZ-RB isolates and the Hawaiian RB-like isolates HA18-9 and HA16- 5 followed by 89 to $90 \%$ nucleotide identity with the T3, VT, and B165 genotypes, 84 to $85 \%$ nucleotide identity with the T36 genotype, and $83 \%$ nucleotide identity with the T30 genotype.

Biological, serological, and molecular relationships among Puerto Rican CTV isolates. CTV-B301 induces symptoms similar to mild CTV-T30-like isolates on 'Mexican' lime and does not induce SP or SY reactions in indicator Citrus spp. Isolate B301 did not induce any symptoms after graft inoculation into 'Carrizo citrange'. The distribution of symptoms of isolate B301 was associated with symptom pattern 1 described by Garnsey et al. (11) (Table 1). Five of the 11 symptom patterns were observed among the Puerto Rican CTV isolates. Symptom pattern 2 was observed in isolates B385 and B386, pattern 4 was observed from isolate B298, pattern 9 from isolates B300 and B392, and pattern 10 from isolates B391, B393, and B394, respectively (Table 1).

Monoclonal antibody MCA13 was previously used in double antibody sandwich (DAS)-ELISA, irrespective of the severity of symptoms induced by CTV isolates, to determine if severe decline inducing isolates were present in a sample in mixed infection. The nine Puerto Rican CTV isolates were tested for reactions with MCA13. Isolates with symptom patterns 1 (B301) and 4 (B298) were MCA13-positive, isolates associated with pattern 10 (B391, B393, and B394) were negative, whereas both positive and negative reactions were observed in isolates associated with symptom patterns 2 (B385 and B386) and 9 (B300 and B392). Two- to fourfold higher DAS-ELISA OD $_{405}$ values were observed for the four MCA13-positive CTV isolates as compared to extracts from healthy plants (Table 1). The MCA13 reaction has been recorded since 1993, when the isolates from Puerto Rico were entered in the EPCC and compared with present ELISA data.

Both multiple molecular marker (MMM) $(14,16)$ and GSP (30) based genotype analyses were conducted for the Puerto Rican CTV isolates and were compared. Symptom patterns 2 and 10 were associated with the T30 genotype (Table 1), symptom pattern 4 with the VT genotype, and symptom pattern 9 with both T36 and RB genotypes, respectively. Although symptom pattern 1 was associated with the T30 genotype, no general relationship was obtained between symptom patterns and genotype profiles. GSPs identified that isolates B298, B301, and B391 were infected with a single genotype of CTV, whereas all of the other six isolates were found to be mixed infections. Isolate B301 infected 'Carrizo citrange' seedlings, and both root and stem tissues contained the CTV dsRNA band of $13.3 \times 10^{6} \mathrm{Da}$, which corresponds to the fulllength replicative form of CTV genomic ssRNA (Fig. 2). The RBGSP was used to confirm the presence of RB genotype utilizing the same dsRNA template in RT-PCR (Fig. 1). Isolate B301 was de-

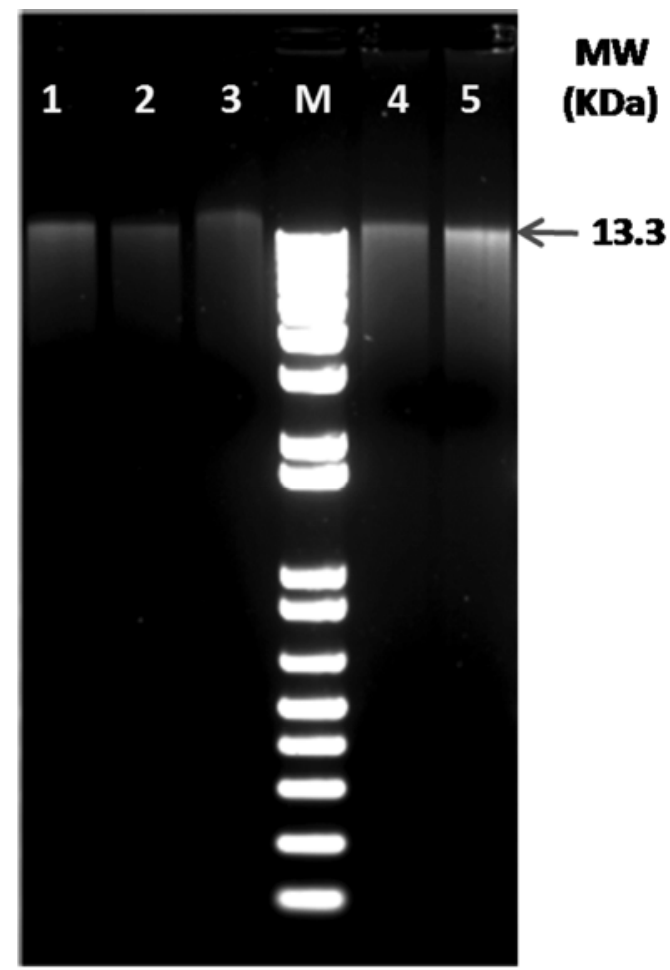

Fig. 2. Comparison of the dsRNA patterns of Citrus tristeza virus (CTV) isolate B301 (Lanes: 1 = root sample, 2 = bark sample) with plants infected with other known CTV isolates: T30 (lane 3), T36 (lane 4), and NZ-KD8 (lane 5). $\mathrm{M}=1 \mathrm{~kb}$ plus DNA ladder from Invitrogen (top most band is $12,000 \mathrm{bp}$ in length). Arrow indicates standard molecular weight $\left(\times 10^{6} \mathrm{Da}\right)$ for CTV dsRNA bands (Lanes 1-3 and 4-5).

Table 1. Biological, serological, and molecular relationships among Puerto Rican Citrus tristeza virus (CTV) isolates

\begin{tabular}{|c|c|c|c|c|c|c|c|c|c|}
\hline Isolates & $\mathbf{L R}^{\mathbf{a}}$ & DEC $^{\mathbf{a}}$ & SYa & GFSPa $^{a}$ & OSPa $^{a}$ & Pattern no. & ELISA MCA13 & $\mathbf{M M M}^{\mathbf{b}}$ & GSP $^{\mathbf{c}}$ \\
\hline B298 & $0.8 /+$ & $0.5 /+$ & $0.8 /+$ & $0.8 /+$ & - & 4 & + & VT & VT \\
\hline B300 & $1.0 /+$ & $1.0 /+$ & - & $0.5 /+$ & - & 9 & + & VT & $\mathrm{T} 36, \mathrm{VT}, \mathrm{RB}$ \\
\hline B301 & $0.5 /+$ & - & - & - & - & 1 & + & Unassigned & $\mathrm{RB}$ \\
\hline B385 & $2.0 /+$ & $0.5 /+$ & - & - & - & 2 & + & T30 & VT, T30 \\
\hline B386 & $2.0 /+$ & $0.5 /+$ & - & - & - & 2 & - & T30 & T3, T30, RB \\
\hline B391 & $1.0 /+$ & - & - & $1.5 /+$ & - & 10 & - & T30 & T30 \\
\hline B392 & $1.5 /+$ & $0.5 /+$ & - & $1.5 /+$ & - & 9 & - & $\mathrm{T} 30$ & T30, T36, RB \\
\hline B393 & $1.0 /+$ & - & - & $1.5 /+$ & - & 10 & - & $\mathrm{T} 30$ & $\mathrm{~T} 30, \mathrm{VT}$ \\
\hline B394 & $1.0 /+$ & - & - & $1.5 /+$ & - & 10 & - & T30 & $\mathrm{T} 30, \mathrm{VT}$ \\
\hline
\end{tabular}

${ }^{a}$ LR = leaf reaction in Mexican lime, DEC = decline symptoms that indicate chlorosis and stunting in the grafted sweet orange scion on sour orange root stock, SY = seedling yellows reaction on sour orange seedlings, GFSP and OSP = grapefruit stem pitting on Duncan cultivar seedlings and sweet orange stem pitting on Madam vinous cultivar seedlings.

b Multiple molecular markers (14).

c Genotype specific primers (30). 
tected from root tissue in 'Carrizo citrange' by the RB-GSPs 2 months after graft inoculation but not in the aboveground tissues. Five months after graft inoculation, the aboveground tissues from the previously infected plants produced amplicons of the expected size $(627 \mathrm{nt})$. This result showed the long-distance virus movement from root to aboveground tissues. The presence of dsRNA in the Carrizo showed that the virus replicated in these tissues and further suggests that CTV-B301 is a trifoliate RB genotype. Similar results were observed on trifoliate orange infected with NZ-RB isolates $(8,13)$. We also found the trifoliate RB genotype in mixed infections with T36 and T30 genotypes, with T3 and T30 genotypes, or with T36 and VT genotypes (Table 1). Phylogenetic analysis of the RB-GSPs amplicon also confirmed the presence of the RB genotype in mixed infections among these Puerto Rican CTV isolates (Fig. 3).

Comparison of the B301 genome with other CTV genomes. The B301 RB isolate was chosen for complete genome sequencing since it was the only Puerto Rican CTV isolate not containing a mixture of genotypes. The genome of B301 was determined to be 19,255 nt in length. All CTV genomes are comparable in total length $(19,226$ to $19,302 \mathrm{nt})$, and all of the ORFs described for each of the genotypic isolates were also present in isolate B301.
The B301 genome had a 95 to $97 \%$ nucleotide sequence identity with the five trifoliate RB CTV isolates from New Zealand. The genome is composed of a long variable ORF1a with a +1 frame shift to produce ORF1b and a conserved ORF2-11. The 5'- and $3^{\prime}-$ UTR of B301 were 107 and 274 nt in length, respectively, and shared 98 to $100 \%$ sequence identities with CTV-RB isolates from New Zealand.

ORF1a of B301 consisted of 9,351 nt that translate into a 349$\mathrm{kDa}$ polyprotein (p349) terminating at nt position 9458 , which contains leader proteases I and II, methyltransferase, the interdomain region, and the helicase-like domains as observed with other CTV isolates (17). ORF1a of B301 had a maximum nucleotide and amino acid identities (93 to 97\%) with the five RB isolates from New Zealand and with an isolate from Hawaii (HA18-9), but had only 88 to $89 \%$ identity with the T36 genotype. ORF1b overlaps ORF1a by $77 \mathrm{nt}$ and continues with the expression of the RNA dependent RNA polymerase (RdRp; p54) via a+1 frameshift. ORF1b of B301 encodes the RdRp-like domain and has identities of 96 to $98 \%$ and 97 to $99 \%$ at nt and aa sequence level, respectively, with the trifoliate-RB isolates from New Zealand (Table 2).

The $3^{\prime}$ terminal half-region (ORFs 2-11) of isolate B301 encodes 10 protein products ranging in size from 6 to $65 \mathrm{kDa}$

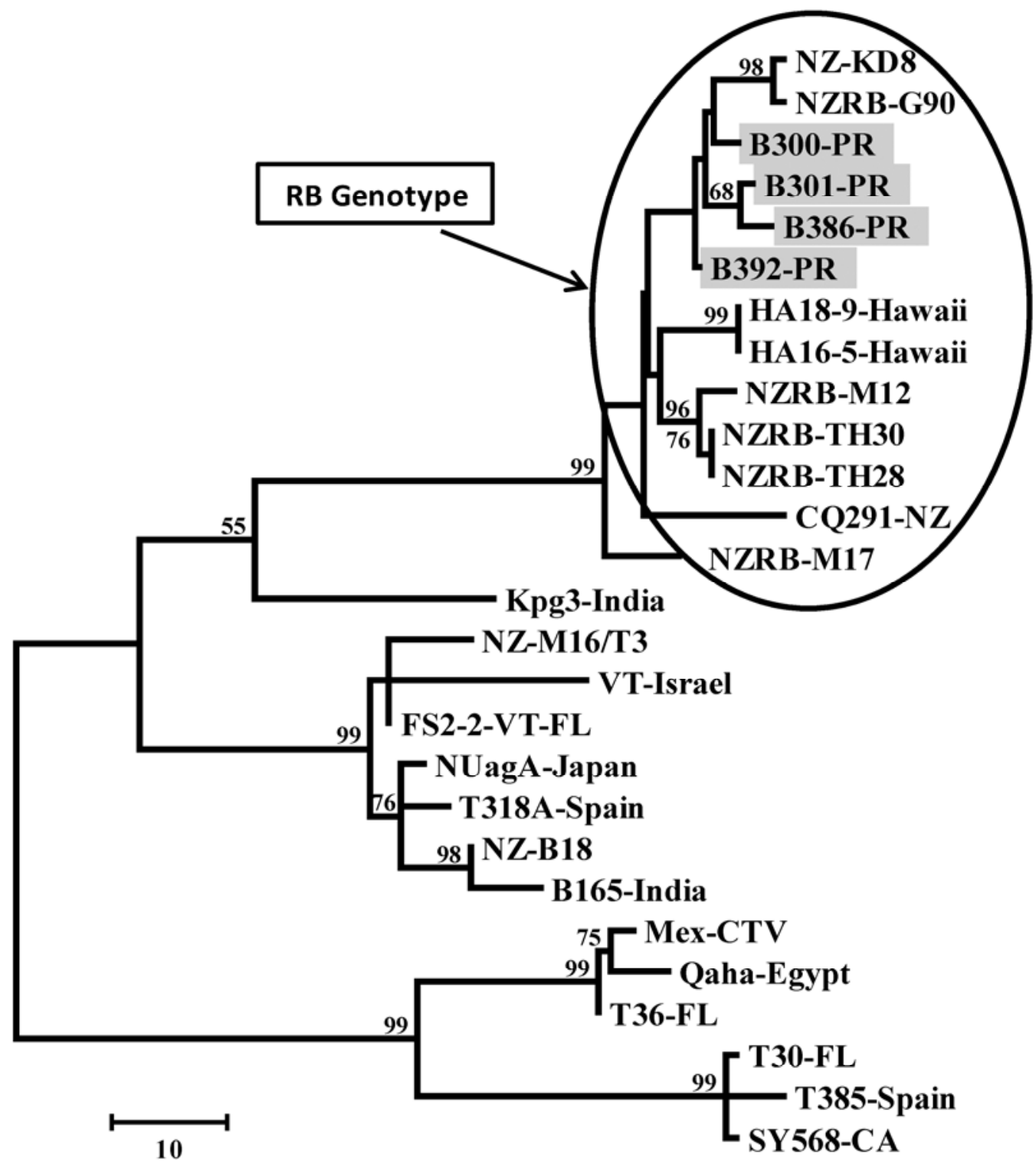

Fig. 3. Phylogenetic analysis of partial heat shock protein (p65) nucleotide sequence reveals the presence of Citrus tristeza virus trifoliate orange resistance breaking (RB) genotypes among Puerto Rican (PR) isolates. The phylogenetic tree was constructed using the MEGA5 program. The phylogenetic group was supported by 1,000 bootstrap replicates. Branch lengths are proportional to the genetic distances. 
$(17,27)$. ORF2-11 of B301 is 8,118 nt in length and has maximum nucleotide sequence identities of 96 to $97 \%$ with other trifoliate RB isolates, but only 88 to $89 \%$ identity with the T36 genotype (Table 2). Nucleotide and amino acid identity of the individual ORFs of isolate B301 with other genotypes are shown in Table 2.

Two phylogenetic trees were constructed using the nucleotide sequences of the variable $5^{\prime}$ terminal-half (ORF1a and $1 \mathrm{~b}$ ) and the conserved $3^{\prime}$ terminal-half regions (ORF2-11) of 21 complete CTV sequences available in GenBank (Fig. 4A and B). In addition to the $5^{\prime}$ and $3^{\prime}$ terminal-half genomes, phylogenetic analysis of the entire genome of B301 suggested that this isolate is a new member in the trifoliate RB genotype group VI (Fig. 4C). Furthermore, phylogenetic analysis of the individual ORFs of B301 also showed that the nearest phylogenetic relationship was with isolate NZRB-G90 followed by NZRB-M12 (FJ525431), -TH28 (FJ525433), -M17 (FJ525435), and -TH30 (FJ525434) isolates, respectively, from New Zealand (data not shown).

Average nucleotide sequence distance between isolate B301 and other CTV genotypes. The average nucleotide sequence distances of different genomic regions between isolate B301 and CTV-RB genotype were shown, utilizing p-distance analysis (Supplementary Table 2). Minimal sequence variation was observed in the $5^{\prime}$ or $3^{\prime}$ terminal-half regions between isolates B301 and trifoliate RB genotypic isolates; however, the average distance between the ORF1a of the RB genotype was greater than for the other 11 ORFs. In an earlier study, the trifoliate CTV-RB genotype was described as a recombinant composed of T36, T30, and VT genotype segments (13). The average nucleotide distances for $5^{\prime}$ (ORF1a and 1b) terminal half-regions between isolate B301 and the T36 genotype were significantly (two- to three-fold) closer than the nucleotide distance between the same regions and T30, VT, T3, and B165 (seven- to nine-fold) genotypes. Analyses of ORFs 2-11 showed that the T30 genotype is more closely (0.076) related to isolate B301 and RB genotypes than to the other four genotypes.
The distance between the complete genome of B301 and the other trifoliate RB isolates was only 0.035 .

\section{Discussion}

Twenty-one full genome CTV sequences from GenBank belonging to six genotypes were aligned and analyzed to identify a conserved nucleotide sequence for designing trifoliate RB-GSPs. Sequence alignments and phylogenetic analyses suggested that $\mathrm{p} 65$, the heat shock protein (ORF4), was an appropriate target region to develop primers for the specific detection of the trifoliate RB genotype. ORF4 is highly variable in the $3^{\prime}$ terminal half-region and has several polymorphic sites that were used to discriminate the trifoliate RB genotype from the five previously described genotypes. Six CTV genotypes can now be distinguished in routine diagnostic assays, but we cannot ignore the possibility of unknown or unassigned genotypes that may exist in nature. For example, a phylogenetic analysis of the $3^{\prime}$ terminal half-region of the recently deposited Indian CTV isolate Kpg3 (HM573451) placed it in a new clade (Fig. 4B). In addition, alignment of the CTV-Kpg3 sequence showed mismatches to the sense and antisense RB-GSP; therefore CTV-Kpg3 is unlikely to be detected by RT-PCR with these genespecific primers (Fig. 3).

Symptoms of the Puerto Rican CTV isolates in bio-index hosts varied in type and severity. Insignificant decline and mild to moderate leaf reaction on 'Mexican' lime was common among the Puerto Rican CTV isolates, but mild SY was observed only with isolate B298. Although some of the isolates produced moderate SP symptoms on 'Duncan' grapefruit, none of the isolates produced SP symptoms on sweet orange. Out of the 11 symptom patterns previously described (11), five were observed among the Puerto Rican CTV isolates, but the most severe symptoms, patterns 5 to 8 , were not observed. The bio-indexing tests confirmed that the EPCC Puerto Rican CTV isolates are of relatively mild to moderate severity (Table 1) as compared to severe reference isolates from different geographical regions (11).

Table 2. Nucleotide and amino acid sequence identities (\%) between isolate B301 (Accession number JF957196) and other Citrus tristeza virus (CTV) genotype isolates $^{\mathrm{a}}$

\begin{tabular}{|c|c|c|c|c|c|c|c|c|c|}
\hline & & \multicolumn{8}{|c|}{ CTV genotypes group and type isolates } \\
\hline \multicolumn{2}{|c|}{ CTV } & \multirow{2}{*}{$\begin{array}{c}\text { I } \\
\text { T36 }\end{array}$} & \multirow{2}{*}{$\begin{array}{c}\text { II } \\
\text { T30 }\end{array}$} & \multirow{2}{*}{$\begin{array}{l}\text { III } \\
\text { VT }\end{array}$} & \multirow{2}{*}{$\begin{array}{l}\text { IV } \\
\text { T3 }\end{array}$} & \multirow{2}{*}{$\begin{array}{c}\mathrm{V} \\
\text { B165 }\end{array}$} & \multirow{2}{*}{$\begin{array}{r}\text { VI } \\
\text { RB }\end{array}$} & \multicolumn{2}{|c|}{$\mathbf{V I}{ }^{\circledR}$} \\
\hline ORF/gene & Sequence type & & & & & & & HA18-9 & HA16-5 \\
\hline \multirow[t]{2}{*}{$1 \mathrm{a}$} & nt & $88-89$ & 72 & $71-73$ & 72 & 72 & $93-97$ & 96 & 72 \\
\hline & aa & $84-85$ & 73 & $71-73$ & 74 & $73-74$ & $93-97$ & 96 & 73 \\
\hline \multirow[t]{2}{*}{$1 b$} & nt & $88-89$ & 82 & $81-82$ & 81 & 81 & $96-98$ & 97 & 77 \\
\hline & aa & $88-93$ & 94 & $81-82$ & 93 & $90-92$ & $97-99$ & 97 & 88 \\
\hline \multirow[t]{2}{*}{$2 / \mathrm{p} 33$} & $\mathrm{nt}$ & 83 & 93 & $83-84$ & 84 & $83-84$ & $95-97$ & 96 & 86 \\
\hline & aa & $83-85$ & $91-92$ & $82-85$ & 85 & 82 & $94-96$ & 95 & 87 \\
\hline \multirow[t]{2}{*}{$3 / \mathrm{p} 6$} & nt & 97 & 96 & $91-94$ & 95 & 96 & $97-98$ & 96 & 98 \\
\hline & aa & $92-94$ & 98 & $94-98$ & 100 & 98 & $96-98$ & 98 & 94 \\
\hline \multirow[t]{2}{*}{ 4/p65 } & $\mathrm{nt}$ & 87 & 87 & $90-92$ & 92 & $91-92$ & $97-98$ & 97 & 97 \\
\hline & aa & $91-93$ & 93 & $93-97$ & 97 & $96-97$ & $97-98$ & 98 & 98 \\
\hline \multirow[t]{2}{*}{$5 / \mathrm{p} 61$} & $\mathrm{nt}$ & $91-93$ & 94 & $87-88$ & 87 & $87-88$ & $96-97$ & 92 & 92 \\
\hline & aa & $91-93$ & 95 & $89-90$ & 89 & $89-90$ & $94-96$ & 92 & 92 \\
\hline \multirow[t]{2}{*}{$6 / \mathrm{p} 27$} & nt & $91-92$ & 95 & 88 & 88 & 89 & $95-96$ & 90 & 90 \\
\hline & aa & $94-95$ & 96 & $94-96$ & 95 & 89 & 97 & 96 & 95 \\
\hline \multirow{2}{*}{$7 / \mathrm{p} 25$} & nt & 94 & 92 & $93-94$ & 93 & 93 & 97 & 92 & 92 \\
\hline & aa & 96 & 96 & 96 & 96 & 97 & $96-97$ & 97 & 97 \\
\hline \multirow[t]{2}{*}{$8 / \mathrm{p} 18$} & $\mathrm{nt}$ & $94-95$ & 94 & 92 & 93 & $92-93$ & $96-97$ & 91 & 91 \\
\hline & aa & $91-95$ & 94 & 91 & 93 & 94 & $95-98$ & 90 & 90 \\
\hline \multirow[t]{2}{*}{ 9/p13 } & nt & $92-93$ & 90 & 91 & 90 & 90 & $94-98$ & 90 & 90 \\
\hline & aa & $89-92$ & 89 & $89-90$ & 91 & 88 & $93-97$ & 88 & 88 \\
\hline \multirow[t]{2}{*}{$10 / \mathrm{p} 20$} & nt & $88-90$ & 92 & 91 & 91 & 92 & $97-98$ & 89 & 89 \\
\hline & aa & $84-94$ & $95-96$ & $94-95$ & 94 & 95 & $98-100$ & 93 & 93 \\
\hline \multirow[t]{2}{*}{$11 / \mathrm{p} 23$} & $\mathrm{nt}$ & $88-89$ & $93-94$ & 89 & 89 & 90 & $96-98$ & 89 & 89 \\
\hline & aa & 88 & $94-95$ & $88-90$ & 88 & 89 & 94-99 & 90 & 90 \\
\hline Full & nt & $88-90$ & 81 & 80 & $80-81$ & 80 & $95-97$ & 95 & 81 \\
\hline
\end{tabular}

a All isolates are grouped as genotype I [T36 (U16304), Qaha (AY340974), and Mexican CTV isolate (DQ272579)], genotype II [T30 (AF260651) and T385 (Y18420)], genotype III [VT (U56902), FS2-2 (EU937519), SY568 (AF001623), NUagA (AB046398), and T318A (DQ151548)], genotype IV [B165 (EU076703) and NZ-B18 (FJ525436)], genotype V [NZ-M16 (EU857538)], genotype VI [NZRB-G90 (FJ525432), -M12 (FJ525431), -M17 (FJ525435), -TH28 (FJ525433), -TH30 (FJ525434)], and genotype VI ${ }^{\circledR}$ [HA18-9 (GQ454869) and HA16-5 (GQ454870)]. ${ }^{\circledR}$ Refers to recombinant resistance breaking genotype. 
Previously, monoclonal antibody MCA13 was applied to distinguish severe decline-inducing CTV strains from nondecline strains (28). Both MCA13-positive and -negative isolates were found among the tested Puerto Rican CTV isolates. MCA13-negative isolates caused moderate SP (except isolate B386), whereas MCA13-positive isolate B301 was symptomless in all tested citrus hosts (Table 1). There was no relationship obtained between the MCA13 reactivity and the symptom pattern of each Puerto Rican isolate. This may be due to mixtures of severe and mild isolates, and suggests that each symptom expression pattern may require specific viral determinants. No relationship was observed between the MCA13 reactivity and the symptom pattern of isolates from Australia, Florida, and Corsica $(5,7,34)$. The MCA13 epitope was mapped to a single amino acid residue at the 124th position in the coat protein gene (28). A nucleotide change, UUU (Phenylalanine) to UAU (Tyrosine) in the coat protein gene of an MCA13-positive, full-length infectious cDNA clone of CTV-T36 did not alter the symptoms produced by infected plants (39). Thus, the MCA13 reactive epitope is not associated with the symptomatology of CTV isolates.

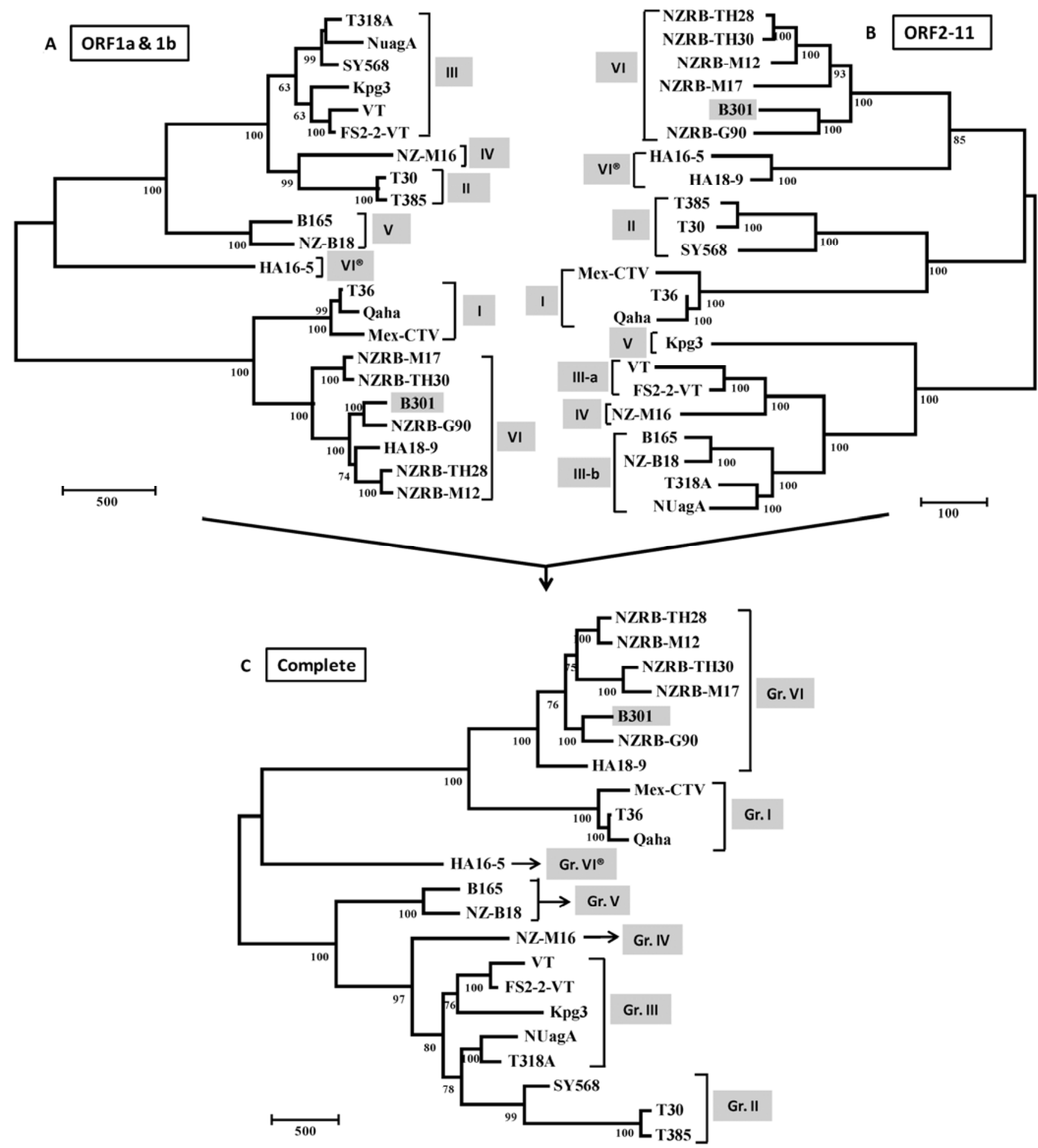

Fig. 4. Phylogenetic analyses of the complete genome (C) and the $5^{\prime}(\mathrm{A})$ and $3^{\prime}(\mathrm{B})$ terminal half-regions of isolate B301 and other Citrus tristeza virus isolates. The phylogenetic tree was constructed using the MEGA5 program. The phylogenetic group was supported by 1,000 bootstrap replicates. Branch lengths are proportional to the genetic distances. ${ }^{\circledR}$ Refers to recombinant resistance breaking genotype. 
Bio-indexing and serological methods using MCA13 in DASELISA were unable to discriminate among known CTV genotypes in mixed infections. Therefore, the GSP-based molecular approach was developed and applied to genotypes of the global collection of CTV isolates at the EPCC (30). The addition of the newly developed primers for the detection of the trifoliate RB genotype further adds to the ability of the CTV GSP detection method for identification of six known CTV genotypes. Based on these methods, five of the six known CTV genotypes are present in Puerto Rico, either singly or as co-infections (Table 1). The MMMs method $(14,16)$ was not able to detect the presence of an unassigned genotype like RB in single or in mixed infections. The newly developed trifoliate RB-GSP discovered the trifoliate-RB genotype for the first time in CTV isolates from Puerto Rico. Since this isolate was collected in 1992, it is presumed to have been there prior to that date. In addition to Puerto Rican CTV isolates, a further 30 isolates from 14 different countries also were screened to determine the worldwide distribution of the CTV-RB genotype. CTV isolates from the EPCC were chosen based on a bio-indexing score (0-1) obtained as described by Garnsey et al. (11). Twelve isolates from six countries (Brazil, Japan, New Zealand, Taiwan, Trinidad, and the United States) were determined to contain the RB genotype and showed 96 to $98 \%$ sequence identity with NZ-RB isolate sequences available at the GenBank (A. Roy and R. H. Brlansky, unpublished). The newly developed RB GSP may be added to the other five GSPs following the methods outlined for previously developed multiplex RT-PCR assay (30).

For further confirmation of the RB genotype, the full genome sequence of B301 was determined, making it the first completely sequenced Puerto Rican CTV isolate. The genome of B301 isolate is similar to other CTV isolates that contain 12 ORFs with a 107 to 109 nt highly variable 5'-UTR and 273 to 274 nt conserved 3 '-UTR $(1,12,13,17,21,22,33,35,41,46,49)$. Comparative sequence analyses of single ORFs from the $5^{\prime}$ - and $3^{\prime}$-terminal half-regions of B301 genomic RNA indicated that B301 was a new member of the trifoliate RB genotype group. The complete genomic sequence had 95 to $97 \%$ nucleotide identities with other reported trifoliate-RB sequences (Table 2). Phylogenetic analyses of the amplicon sequences from $5^{\prime}$ (ORF1a and $1 \mathrm{~b}$ ) and $3^{\prime}$ terminal half regions (ORF2-11) also placed B301 into RB genotype cluster VI. Furthermore, the complete genome sequence of B301 and its 12 ORFs showed it to be closely related to trifoliate RB genotype (VI) isolates. The average nucleotide distance between all 12 conserved ORFs of B301 and the six CTV genotypes suggested that there was a stronger relationship between B301 and the trifoliate RB genotype (group VI) than with the T30 (group II) and T36 (group I) genotype isolates.

In this study, we designed and standardized a trifoliate RB-GSPbased assay. This is the first report of development, standardization, and application of a trifoliate RB-GSP-based assay utilizing RT-PCR. We classified the unassigned B301 isolate as a new member of the trifoliate RB genotype group and also identified hidden trifoliate-RB genotypes in mixed infection with other genotypes in CTV isolates from Puerto Rico. This is also the first report of the complete nucleotide sequence of a Puerto Rican CTV isolate. Previously, trifoliate RB genotypes were reported only from New Zealand (13). Although Hawaiian CTV isolates appear genetically related to the NZ-RB isolates, there is no published evidence that those two isolates are able to infect trifoliate orange. Thus, RBGSP should be applied more widely to better understand the significance and potential impact on worldwide distribution of the genotype suspected of being trifoliate-RB.

\section{Acknowledgments}

We are grateful to S. M. Garnsey for depositing the Puerto Rican CTV isolates in the Exotic Pathogens of Citrus Collection (EPCC), Beltsville, MD and sharing the bio-indexing data with us. Thanks to Ruhui Li and Rosemarie W. Hammond, USDA-ARS, Beltsville, MD, for useful discussion and critical comments on the manuscript. The authors extend their thanks to Cristina Paul for providing the CTV-B301 extracts from the EPCC, Beltsville, MD.

\section{Literature Cited}

1. Albiach-Martí, M. R., Mawassi, M., Gowda, S., Satyanarayana, T., Hilf, M. E., Shanker, S., Almira, E. C., Vives, M. C., López, C., Guerri, J., Flores, R., Moreno, P., Garnsey, S. M., and Dawson, W. O. 2000. Sequences of Citrus tristeza virus separated in time and space are essentially identical. J. Virol. 74:6856-6865.

2. Ayllón, M. A., López, C., Navas-Castillo, J., Garnsey, S. M., Guerri, J., Flores, R., and Moreno, P. 2001. Polymorphism of the $5^{\prime}$ terminal region of citrus tristeza virus (CTV) RNA: Incidence of three sequence types in isolates of different origin and pathogenicity. Arch. Virol. 146:27-40.

3. Ayllón, M. A., López, C., Navas-Castillo, J., Mawassi, M., Dawson, W. O., Guerri, J., Flores, R., and Moreno, P. 1999. New defective RNAs from citrus tristeza virus: Evidence for a replicase-driven template switching mechanism in their generation. J. Gen. Virol. 80:817-821.

4. Bar-Joseph, M., and Lee, R. F. 1989. Citrus tristeza virus. AAB Descr. Plant Viruses No. 353

5. Brlansky, R. H., Damsteegt, V. D., Howd, D. S., and Roy, A. 2003. Molecular analyses of Citrus tristeza virus subisolates separated by aphid transmission. Plant Dis. 87:397-401.

6. Brlansky, R. H., Roy, A., and Damsteegt, V. D. 2011. Stem-pitting Citrus tristeza virus predominantly transmitted by the brown citrus aphid from mixed infections containing non-stem-pitting and stem-pitting isolates. Plant Dis. 95:913-920.

7. Broadbent, P., Brlansky, R. H., and Indsto, J. 1996. Biological characterization of Australian isolates of citrus tristeza virus and separation of subisolates by single aphid transmissions. Plant Dis. 80:329-333.

8. Dawson, T. E., and Mooney, P. A. 2000. Evidence for trifoliate resistance breaking isolates of Citrus tristeza virus in New Zealand. Pages 69-76 in: Proc. 14th Conf. Int. Organ. Citrus Virol. J. V. da Graca, R. F. Lee, and R. K. Yokomi, eds. International Organization of Citrus Virologists, Riverside, CA.

9. Febres, V. J., Ashoulin, L., Mawasi, M., Frank, A., Bar-Joseph, M., Manjunath, K. L., Lee, R. F., and Niblett, C. L. 1996. The p27 protein is present at one end of citrus tristeza virus particles. Phytopathology 86:1331-1335.

10. Felsenstein, J. 1985. Confidence limits on phylogenies: An approach using the bootstrap. Evolution 39:783-791.

11. Garnsey, S. M., Civerolo, E., Gumpf, D. J., Paul, C., Hilf, M. E., Lee, R. F., Brlansky, R. H., Yokomi, R. K., and Hartung, J. S. 2005. Biological characterization of an international collection of Citrus tristeza virus (CTV) isolates. Pages 75-93 in: Proc. 16th Conf. Int. Organ. Citrus Virol. M. E. Hilf, N. Duran-Vila, and M. A. Rocha-Peña, eds. International Organization of Citrus Virologists, Riverside, CA.

12. Harper, S. J., Dawson, T. E., and Pearson, M. N. 2009. Complete genome sequences of two distinct and diverse Citrus tristeza virus isolates from New Zealand. Arch. Virol. 154:1505-1510.

13. Harper, S. J., Dawson, T. E., and Pearson, M. N. 2010. Isolates of Citrus tristeza virus that overcome Poncirus trifoliata resistance comprise a novel strain. Arch. Virol. 155:471-480.

14. Hilf, M. E., Karasev, A. V., Albiach-Martí, M. R., Dawson, W. O., and Garnsey, S. M. 1999. Two paths of sequence divergence in the Citrus tristeza virus complex. Phytopathology 89:336-342.

15. Hilf, M. E., Karasev, A. V., Pappu, H. R., Gumpf, D. J., Niblett, C. L., and Garnsey, S. M. 1995. Characterization of citrus tristeza virus subgenomic RNAs in infected tissue. Virology 208:576-582.

16. Hilf, M. E., Mavrodieva, V. A., and Garnsey, S. M. 2005. Genetic marker analysis of a global collection of isolates of Citrus tristeza virus: Characterization and distribution of CTV genotypes and association with symptoms. Phytopathology 95:909-917.

17. Karasev, A. V., Boyko, V. P., Gowda, S., Nikolaeva, O. V., Hilf, M. E., Koonin, E. V., Nibblet, C. L., Cline, K., Gumpf, D. J., Lee, R. F., Garnsey, S. M., and Dawson, W. O. 1995. Complete sequence of the Citrus tristeza virus RNA genome. Virology 208:511-520.

18. Karasev, A. V., Hilf, M. E., Garnsey, S. M., and Dawson, W. O. 1997. Transcriptional strategy of closteroviruses: Mapping the $5^{\prime}$ termini of the citrus tristeza virus subgenomic RNAs. J. Virol. 71:6233-6236.

19. Lu, R., Folimonov, A., Shintaku, M., Li, W. X., Falk, B. W., Dawson, W. O., and Ding, S. W. 2004. Three distinct suppressors of RNA silencing encoded by a 20-kb viral RNA genome. Proc. Natl. Acad. Sci. USA 101:1574215747.

20. Mawassi, M., Karasev, A. V., Mietkiewska, E., Gafny, R., Lee, R. F., Dawson, W. O., and Bar-Joseph, M. 1995. Defective RNA molecules associated with citrus tristeza virus. Virology 208:383-387.

21. Mawassi, M., Mietkiewska, E., Gofman, R., Yang, G., and Bar-Joseph, M 1996. Unusual sequence relationship between two isolates of Citrus tristeza virus. J. Gen. Virol. 77:2359-2364.

22. Melzer, M. J., Wayne, B. B., Diane, M. S., Stephen, F., Dennis, G., and John, S. H. 2010. Genetic diversity and evidence for recent modular recombination in Hawaiian Citrus tristeza virus. Virus Genes 40:111-118.

23. Moreno, P., Ambrós, S., Albiach-Martí, M. R., Guerri, J., and Pená, L. 2008. Citrus tristeza virus: A pathogen that changed the course of the citrus industry. Mol. Plant Pathol. 9:251-268.

24. Moreno, P., and Guerri, J. 1997. Variability of citrus tristeza closterovirus (CTV): Methods to differentiate isolates. Pages 97-107 in: Filamentous Vi- 
ruses of Woody Plants. P. Monette, ed. Research Signpost, Trivandrum, India.

25. Nei, M., and Kumar, S. 2000. Molecular evolution and phylogenetics. Oxford University Press, New York.

26. Nicholas, K. B., and Nicholas, H. B., Jr. 1997. GeneDoc: A tool for editing and annotating multiple sequence alignments. www.psc.edu/biomed/genedoc

27. Pappu, H. R., Karasev, A. V., Anderson, E. J., Pappu, S. S., Hilf, M. E., Febres, V. J., Eckloff, R. M. G., McCaffery, M., Boyko, V., Gowda, S., Dolja, V. V., Koonin, E. V., Gumpf, D. J., Cline, K. C., Garnsey, S. M., Dawson, W. O., Lee, R. F., and Niblett, C. L. 1994. Nucleotide sequence and organization of eight open reading frames of the citrus tristeza closterovirus genome. Virology 199:35-46.

28. Permar, T. A., Garnsey, S. M., Gumpf, D. J., and Lee, R. F. 1990. A monoclonal antibody which discriminates strains of Citrus tristeza virus. Phytopathology 80:224-228

29. Roistacher, C. N., and Moreno, P. 1991. The worldwide threat from destructive isolates of citrus tristeza virus-a review. Pages 7-19 in: Proc. 11th Conf. Int. Organ. Citrus Virol. R. H. Brlansky, R. F. Lee, and L. W. Timmer, eds. International Organization of Citrus Virologists, Riverside, CA.

30. Roy, A., Ananthakrishnan, G., Hartung, J. S., and Brlansky, R. H. 2010. Development and application of a multiplex reverse transcription polymerase chain reaction assay for screening a global collection of Citrus tristeza virus isolates. Phytopathology 100:1077-1088.

31. Roy, A., and Brlansky, R. H. 2004. Genotype classification and molecular evidence for the presence of mixed infections in Indian citrus tristeza virus isolates. Arch. Virol. 149:1911-1929.

32. Roy, A., and Brlansky, R. H. 2009. Population dynamics of a Florida Citrus tristeza virus isolate and aphid-transmitted subisolates: Identification of three genotypic groups and recombinants after aphid transmission. Phytopathology 99:1297-1306.

33. Roy, A., and Brlansky, R. H. 2010. Genome analysis of an orange stem pitting Citrus tristeza virus isolate reveals a novel recombinant genotype. Virus Res. 151(2):118-130.

34. Roy, A., Choudhary, N., Damsteegt, V. D., Hartung, J. S., and Brlansky, R. H. 2010. Complete $3^{\prime}$ end genome analysis of the asymptomatic Citrus tristeza virus isolate B192 and its eight symptomatic single aphid transmitted subisolates. (Abstr.) Phytopathology 100:S111.

35. Ruiz-Ruiz, S., Moreno, P., Guerri, J., and Ambrós, S. 2006. The complete nucleotide sequence of a severe stem pitting isolate of citrus tristeza virus from Spain: Comparison with isolates from different origins. Arch. Virol. 151:387-398.

36. Saitou, N., and Nei, M. 1987. The neighbor-joining method: A new method for reconstructing phylogenetic trees. Mol. Biol. Evol. 4:406-425.

37. Satyanarayana, T., Gowda, S., Ayllón, M. A., and Dawson, W. O. 2004. Closterovirus bipolar virion: Evidence for initiation of assembly by minor coat protein and its restriction to the genomic RNA 5' region. Proc. Natl. Acad. Sci. USA 101:799-804.
38. Satyanarayana, T., Gowda, S., Mawassi, M., Albiach-Martí, M. R., Ayllón, M. A., Robertson, C. J., Garnsey, S. M., and Dawson, W. O. 2000. Closterovirus encoded HSP70 homolog and p61 in addition to both coat proteins function in efficient virion assembly. Virology 1278:253-265.

39. Satyanarayana, T., Robertson, C. J., Garnsey, S. M., and Dawson, W. O. 2005. Generation of a genetically engineered MCA13 nonreactive variant of the T36 decline isolate of citrus tristeza virus. Pages 34-43 in: Proc. 16th Conf. Int. Organ. Citrus Virol. M. E. Hilf, N. Duran-Vila, and M. A. Rocha-Peña, eds. International Organization of Citrus Virologists, Riverside, CA.

40. Satyanarayana, T., Robertson, C. J., Garnsey, S. M., and Dawson, W. O. 2011. A plant virus evolved by acquiring multiple nonconserved genes to extend its host range. Proc. Natl. Acad. Sci. USA 108(42):17366-17371.

41. Suastika, G., Natsuaki, T., Terui, H., Kano, T., Ieki, H., and Okuda, S. 2001 Nucleotide sequence of Citrus tristeza virus seedling yellows isolate. J. Gen. Plant Pathol. 67:73-77.

42. Tamura, K., Peterson, D., Peterson, N., Stecher, G., Nei, M., and Kumar, S. 2011. MEGA5: Molecular Evolutionary Genetics Analysis using Maximum Likelihood, Evolutionary Distance, and Maximum Parsimony Methods. Mol. Biol. Evol. doi: 10.1093/molbev/msr121

43. Tatineni, S., Robertson, C. J., Garnsey, S. M., Bar-Joseph, M., Gowda, S., and Dawson, W. O. 2008. Three genes of citrus tristeza virus are dispensable for infection and movement throughout some varieties of citrus trees. Virology 376:297-307.

44. Thompson, J. D., Gibson, T. J., Plewniak, F., Jeanmougin, F., and Higgins, D. G. 1997. The Clustal X windows interface: Flexible strategies for multiple sequence alignment aided by quality analysis tools. Nucleic Acids Res. 24:4876-4882.

45. Valverde, R. A., Nameth, S. T., and Jordan, R. L. 1990. Analysis of doublestranded RNA for plant virus diagnostic. Plant Dis. 74:255-258.

46. Vives, M. C., Rubio, L., Lopez, C., Navas-Castillo, J., Albiach-Martí, M. R. Dawson, W. O., Guerri, J., Flores, R., and Moreno, P. 1999. The complete genome sequence of the major component of a mild citrus tristeza virus isolate. J. Gen. Virol. 80:811-816.

47. Weng, Z., Barthelson, R., Gowda, S., Hilf, M. E., Dawson, W. O., Galbraith, D. W., and Xiong, Z. 2007. Persistent infection and promiscuous recombination of multiple genotypes of an RNA virus within a single host generate extensive diversity. PLoS One 2(9):e917.

48. Yang, G., Mawassi, M., Gofman, R., Gafny, R., and Bar-Joseph, M. 1997. Involvement of a subgenomic mRNA in the generation of a variable population of defective citrus tristeza virus molecules. J. Virol. 71:9800-9802.

49. Yang, Z. N., Mathews, D. H., Dodds, J. A., and Mirkov, T. E. 1999. Molecular characterization of an isolate of Citrus tristeza virus that causes severe symptoms in sweet orange. Virus Genes 19:131-142.

50. Zhang, J., Rosenberg, H. F., and Nei, M. 1998. Positive Darwinian selection after gene duplication in primate ribonuclease genes. Proc. Natl. Acad. Sci. USA 95:3708-3713. 